\section{Mongolian Higher Education in Transition}

\section{John C. Weidman and John L. Yeager}

John C. Weidman is professor of higher education and sociology at the University of Pittsburgh. John L. Yeager is associate professor of higher education at the University of Pittsburgh. Address: Department of Administrative and Policy Studies 5501 Forbes Quadrangle, Pittsburgh, PA 15260, USA. FAX: (4 12) 648-1784 E-mail: <weidman+@pitt.edu>.

$\mathrm{T}$ he rapid change in the higher education system of Mongolia over the past decade reflects several unique aspects, especially in comparison with the systems in the newly independent states of the former Soviet Union. In part, this is due to its unique location and political history, which enable it to draw for assistance upon both the East (Japan, Korea, and the Asian Development Bank) and the West (the European Union and the United States). It is also due, in part, to the unique course Mongolia has taken with respect to the funding of higher education.

The Mongolian People's Republic was established in 1924 as the world's second communist country; the single-party government held onto power until 1990. Mongolia maintained close political and economic ties with the USSR, but was never one of its constituent republics. At the peak of this relationship, almost a third of Mongolia's GDP was provided by the Soviet Union. This included significant support (e.g., books, equipment, and the training of academics and researchers) for Mongolian higher education.

The higher education system on the eve of the transition in 1990 reflected its Soviet roots: highly specialized, with only one, relatively comprehensive (arts and sciences disciplines, secondary school pedagogy, law), institution (the National University of Mongolia) existing alongside independent, specialized, universitylevel institutions for medicine, engineering, agriculture, pedagogy, and the arts and culture. All public institutions had student enrollments quotas set by the National Planning Board, based on anticipated demand for graduates trained in each narrowly defined specialization.

After the fall of the Soviet Union in 1991, external financial support evaporated, and a democratic political structure was established to guide this landlocked country of 2.4 million people through a series of transitions:

- political-from single-party rule to a multiparty democracy, based on a national constitution; from strong ideological monitoring to tolerance of pluralism; and from centralization to decentralization;

- economic-from a command (centrally planned) to a market economy; from state to private ownership of property; from government revenues generated by stateowned enterprises to taxes on personal income and pri- vate enterprises; and

- social-from a "classless" society to status based on personal achievement and earned income; from collective to personal responsibility; from government-provided health care and a social "safety net" to individually paid health insurance and limited government involvement.

Under the "socialist" political structure, institutional autonomy did not exist. Government plans specified, in detail, the funds authorized for expenditure by each higher education institution, the structure and content of the curriculum, faculty workload and compensation, number of students, and the placement of graduates. Under a democratic political structure, these functions have increasingly become the responsibility of individual higher education institutions. However, despite receiving advice from external consultants to consolidate and rationalize the system ( 88 percent of the nation's public higher education students are enrolled in Ulaanbaatar), virtually the same specialized institutions remain in place at the end of the 1990s as existed at the end of the Soviet era.

\section{The higher education system on the eve of the transition in 1990 reflected its Soviet roots}

Mongolia is unique among developing nations in shifting the burden of payment from the government almost entirely to the students, effectively "privatizing" public higher education. Initially, the government provided funds for building maintenance and upkeep, but since 1997, only heat, water, and electricity costs are provided, an amount equal to just over 10 percent of their budgets. Virtually all institutions have ancillary enterprises that generate income, the most common being animal herds.

Individual institutions have substantial control over their own budgets but the Ministry of Science, Technology, Education, and Culture (MOSTEC) still imposes caps on tuition levels. Consequently, inflation-adjusted annual tuition costs have remained at the same relative level (about the equivalent of four months' salary of a senior university lecturer or senior government employee) as when the fee structure was first introduced in 1993. There is a government loan scheme to assist students scoring highest on the admissions exams, with priority given to those enrolling in fields still covered by the government quota system. Facilities, equipment, libraries, and other academic re- 
sources (including advanced-degree training of faculty) that were highly subsidized are now, however, badly in need of renewal.

The unicameral Parliament authorized the establishment of the first private higher education institutions in 1991, thereby introducing further competition. Most private higher education institutions were established for specific types of curricula (especially foreign languages, business, Mongolian culture, and law). None have broadly based, introductory liberal arts courses.

\section{Mongolia is unique among developing nations in shifting the burden of pay- ment from the government almost en- tirely to the students, effectively "privatizing" public higher education.}

A major current concern is quality assurance, especially with respect to trying to make certain that Mongolian degrees are comparable with those earned by graduates of universities in other countries. MOSTEC remains responsible for licensing new higher education institutions, but a national accreditation agency has been established that will function as an independent, nongovernmental body for quality assurance. While many in MOSTEC as well as in the leading national universities would like to have the accreditation process provide a mechanism for closing substandard institutions, so little information exists about the quality of individual higher education institutions that the first phase is most likely to focus on obtaining documentation of actual academic programs and activities on a formative level with more summative assessments to occur at some point in the future.

Government quotas have been relaxed, and admissions are based increasingly on student demand. Despite the high fees, there was a rapid increase in enrollments between 1993-94 and 1996-97: from 17,535 to 25,751 full-time students in public higher education (a 46 percent increase) and from 3,875 to 10,456 fulltime students in private higher education (a 170 percent increase). The proportion of the total full-time higher education enrollments in private institutions increased from 18 to 29 percent over this three-year period. Unlike elsewhere in Asia, female students far outnumber males in Mongolian higher education, constituting 68 and 71 percent, respectively, of the enrollments in public and private institutions. While there has been some reduction in enrollment growth, student demand remains extremely strong, especially in fields like foreign languages, business and management, law, and computer science.

In 1993, with the support of Asian Development Bank (ADB), Mongolia initiated large-scale systematic planning and development work, based on the new political and economic assumptions. The ADB funded a comprehensive education and human resource sector study that was used as the basis for developing a master plan to guide future legislation as well as the development of subsequent projects.

The ADB has provided subsequent grant funding for technical assistance in developing of higher education policies as well as in strengthening the internal management and operational capacity of the leadership of both MOSTEC and higher education institutions. Through the creation of a parallel initiative, the ADB issued loans to fund an Education Sector Development Program that will accelerate the implementation of these policies; continue to expand training opportunities; provide technical assistance to reform efforts; develop curriculum in such areas as pre- and in-service teacher education, economics, and business; and acquire modern laboratory equipment as well as modernize and construct new educational facilities. Mongolia is also benefiting from its European ties through funding for business and economics programs provided by the $\mathrm{Eu}-$ ropean Union and primary education reform funded by the Open Society Institute (Soros Foundation).

\section{A major current concern is quality as- surance, especially with respect to try- ing to make certain that Mongolian degrees are comparable with those earned by graduates of universities in other countries.}

It remains to be seen, however, how quickly the quality of graduates can be brought up to an international standard or whether the labor market will be able expand to grow and absorb the numbers of graduates resulting from the burgeoning demand for higher education in Mongolia. The year 1998 was also one of national political instability as reflected in the demise of three sets of cabinet ministers. Donors have shown reluctance to continue providing funding for needed projects in the absence of a stable government. Expanding the labor market for professional employees, improving quality, and reestablishing political stability are continuing challenges that affect Mongolian higher education in this transitional period. 